\title{
17. What Can We Learn from International Evidence on Trends in Income Distribution?
}

\author{
Henry Ergas ${ }^{1}$
}

\section{Introduction}

In an essay comparing living standards in Australia and Japan, Ian Castles described the challenge for policymakers as being that of using 'the skills and strengths of their peoples to improve opportunities for the enhancement of their well-being in its broadest sense' (Castles, 1990: 16). There was, he noted, 'little point in trying to encapsulate the differences [in wellbeing] in any single measure' (ibid: 15), but that hardly meant one should not attempt to measure carefully what could be measured. It was in that spirit that Castles undertook several international comparisons of living standards and income distribution, including between Australia, Japan, Sweden and the United States (Castles, 1984, 1990).

Read today, those comparisons stand out for the care Castles took to rest his assessment on a sound analytical base. Indeed, there are respects in which those comparisons remain unmatched, notably in adjusting PPP exchange rates to reflect differences in consumption baskets by income group. Thus, Castles was particularly attentive to the fact that relative prices were lower in Australia than in comparator countries for the goods and services which feature particularly prominently in the consumption baskets of lower income households. Although the biases in PPP exchange rates are well known (Almås, 2012), they are rarely taken into account and even more rarely as scrupulously as they were by Castles.

Castles' attention to those adjustments is both a testament to the quality of his work and suggestive of the motivations underpinning his comparisons of income distribution. Although his presentation is anything but polemical, it is difficult to resist the impression that his studies responded, at least in part, to claims that the distribution of incomes in Australia was unequal by international standards. Castles showed that that view was unduly simplistic, and that while the distribution of incomes in Australia was perhaps less equal than in Sweden

1 Many thanks but no blame due to Jonathan Pincus, Peter Whiteford, Alex Robson, Peter Crone, David Henderson and Andrew Podger. 
(though more equal than in the United States and Japan), living standards for low-income Australians were still very high both in comparative and absolute terms.

Since then, concerns about distribution have, if anything, become more pronounced - indeed, the previous Treasurer claimed that the distribution of income and wealth is the commanding issue facing Australians (Swan, 2012). That claim will be surprising to those who recall John Kenneth Galbraith's The Affluent Society. 'Few things are more evident in modern social history', Galbraith wrote in what was certainly no paean to free markets, 'than the decline of interest in inequality as an economic issue' (Galbraith, 1958: 82). The reason for that decline, said Galbraith, was simple: the triumph of economic growth, which ensured prosperity (at least in its 'private affluence' variety) through rising incomes for all, rather than by shuffling incomes around.

By the time Castles wrote, however, that phase was over, and even economic growth itself was contested as a value, provoking Castles into a brilliant defence of economic growth (Castles, 1973). In such a mood of (poorly informed) pessimism, the focus on issues of distribution was perhaps understandable. But once growth returned, that focus did not disappear. On the contrary, writing at the end of a remarkable phase of global economic expansion, which had lifted hundreds of millions of people out of misery, Angel Gurria, the Secretary General of the OECD, called 'fears of rising income inequalities and poverty' issues that 'require correcting the asymmetries in the costs and benefits of globalization' (OECD, 2008: 3). Returning to the theme in 2011, in a preface to an OECD report on trends in income distribution, the Secretary-General expressed those views yet more strongly. 'Popular discontent' about income distribution, he wrote, 'is spreading rapidly'; and rightly so, for the OECD report 'dispels the assumption that the benefits of economic growth will automatically trickle down to the disadvantaged' (OECD, 2011: 18-19). That the 400-page OECD report never discussed the relation between economic growth and income distribution did not prevent the Secretary-General from concluding that 'without a strategy for inclusive growth', including tax and other measures to 'counter rising inequality', 'inequality will continue to rise' (OECD, 2011: 19).

That those views have wide resonance is difficult to doubt. And it is indeed true that the distribution of income in most OECD countries has become somewhat more unequal, though any such conclusion involves a number of issues of measurement and interpretation discussed below. But before turning to those issues it is worth noting quite how small the changes have been relative to the concerns they have provoked.

The rise in the Gini coefficient for the distribution of market incomes in Australia is a case in point. From 1985 to the present, the Gini coefficient for market income increased by some 0.06 points. Using the methodology set out in Blackburn 
(1989), that rise corresponds to shifting around six per cent of average market income from those below the median market income to those above it. Of course, expressed as a share of below median incomes, that proportion would be higher, say 12 per cent. However, merely over the much shorter period from 1995 to the present, real market incomes for the bottom decile more than doubled (calculated from OECD, 2011: 23).

As a result, if it is indeed correct that - as Kuznets (1955) famously surmised periods of growth based on rapid structural change involve an initial widening in the distribution of market incomes, the slight rise in inequality seems a small price to pay. Additionally, it is readily seen that if policies aimed at reversing the rise in inequality reduce economic growth, their costs, even to those they are aimed at assisting, could readily exceed the benefits.

The case for caution in tinkering with market-driven changes is all the stronger in Australia, where it is not clear that there is a problem policy needs to solve. On the contrary, developments in the Australian income distribution seem something of a success story. It is helpful to set out some features of that story as background (noting that they are discussed more fully by Peter Whiteford and Robert Bray, in this volume) before turning to the substance of this paper.

Simplifying to a headline level the basic trends over the period from the mid1980s to the onset of the Global Financial Crisis (drawn from OECD, 2008 and OECD, 2011, and highlighting, in italics, the different income concepts) are these:

- As in other OECD countries, the largest single factor changing the distribution of market income was changes in the distribution of labour earnings;

- However, the OECD data suggest that in contrast to what happened elsewhere, we experienced a compression in the distribution of real wages, as the relative wages of lower paid workers increased;

- But the impact of this on the distribution of earnings from employment was partly offset by changes in average hours worked, which diminished at the bottom end of the wage distribution while increasing at the top. While these shifts also happened elsewhere, a difference in Australia was that hours increased for that group whose relative wages fell (that is, above the median of the wage distribution), while falling for those for whom they increased (that is, below the median of the wage distribution). Had the responses gone the other way - in other words, had labour supply been elastic - the changes in hours would have reinforced, rather than offset, the change in the wage distribution, as happened in the United States;

- At the same time, as unemployment diminished and participation increased, the distribution of market income in the working age population became somewhat more even, relative to the distribution of income from employment, as also tended to happen (albeit to differing extents) elsewhere; 
- Nonetheless, taking account of taxes and income transfers, there was some increase in the Gini coefficient for the distribution of disposable income between households, probably in the order of 0.03 points.

That this story has many positive features is clear. For instance, increased participation was related to strong demand for labour, greater flexibility in employment contracts and the associated increased availability of part-time work, reduced effective marginal tax rates for some income earners and restrictions on access to, and the generosity of, some income transfers. At the same time, the change in the pattern of hours (whereby hours increased significantly for high income earners, while diminishing for low income earners) could reflect socially desirable responses to lower marginal tax rates at the top and to the greater availability of part-time work at the bottom and in the middle of the earnings distribution. ${ }^{2}$ To that extent, these factors would move the economy in the direction of a more efficient use of resources.

Yet it is also clear that there are questions. For instance, the compression of the real wage distribution might reflect a greater net supply shift than elsewhere towards better skilled workers, or it could reflect a lesser net demand shift towards better skilled jobs. In other words, there must at least be the possibility that there was less technological change than elsewhere and/or that it was less skill-biased.

Equally, while the change in hours could reflect the socially desirable responses set out above, the pattern of that shift does seem somewhat unexpected, as one would have expected labour supply to be relatively elastic below the median income level and relatively inelastic at the higher end of the income distribution. While the observed shifts were slight, it remains the case that had that pattern of elasticities held, as in the United States, the changes in hours would have accentuated rather than offset the impact of changes in wage relativities on the distribution of earnings. Yet hours diminished at the bottom, where relative wages were rising, and increased at the top. Moreover, at the top, the participation rate of married women in couples with at least one income earner seems to have increased less than elsewhere, though the earnings of those who did work increased in line with elsewhere. Given those trends, it may be that the tax and transfer systems continue to discourage labour supply both at the lower and at the upper end of the income distribution. ${ }^{3}$

Addressing these questions would go far beyond my scope. But they do highlight the complexities involved in disentangling changes in the distribution

2 The recession of the early 1990s may have been a stronger factor in increasing part-time employment in that period, but part-time job growth subsequently remained strong even as the unemployment rate fell to or even below the Non-Accelerating Inflation Rate of Unemployment.

3 It is of course possible for labour supply curves to be backwards bending, but, absent policy distortions, it would be surprising for them to be in the backward sloping segment at both the top and the bottom of the 
of incomes - much as Castles said about economic growth, those changes are not an instrument governments can sensibly seek to control directly: they " come out" of the complex of decisions made by governments, institutions and individuals ... (and are) to be neither pursued nor shunned' (Castles, 1973:1). It is in the light of, and by reference to, those complexities that in this chapter I seek to make four points: first, not all apparent increases in income inequality are a bad thing; second, not all apparent reductions in income inequality are a good thing; third, even those aspects of the trends that might be problematic may not be as worrying as commonly made out; and fourth and last, some of the proposed policy approaches central to what the OECD Secretary-General has termed 'inclusive growth' merit a healthy degree of skepticism.

\section{Not all increases in inequality are bad for you}

Were incomes merely endowments, there would be little justification for distributing them unequally, rather than on the basis of needs. ${ }^{4}$ In reality, however, incomes are sensitive to investments in effort and in foregoing current consumption for the sake of future abilities. Moreover, market prices for the capabilities created by those investments play an important allocative role, guiding the investments themselves and ensuring acquired skills (and innate abilities) are put to their most highly valued uses. Since redistributive policies distort those signals, 'we cannot', as Arthur Okun used to say, 'have our cake of market efficiency and share it equitably'.

All that is not likely to be contentious, at least among those who have given these matters any thought. Indeed, even the late GA (Jerry) Cohen, an eminent political philosopher and unrepentant Marxist, only a few years ago concluded, after a life time of efforts to show the opposite, that attempts to bypass the informational and incentive functions of market prices were utopian (Cohen, 2009). But none of that means changes in income distribution should necessarily be viewed benignly; and it is understandable that an apparent widening in disparities would at least give rise to questions and possibly concerns. However, in answering those questions, it is crucial to look behind the simpler indicators.

There is, in particular, a risk that relying on aggregate measures of income distribution will hide important shifts occurring within the aggregate - shifts that are more to be applauded than condemned. Three examples make the point.

First, there is considerable evidence that the earnings gap between men and women has narrowed. Thus, examining data for the United States, Welch

4 Giving kidney transplants to those who need them, but not to those who don't, is unequal (in Rae's sense of 'lot regarding inequality', which gives the same shoes to all, despite differences in foot size-Rae, 1981) but not inequitable, at least in Aristotle's sense of proportionate equality. 
(1999) finds that over the period from 1967 to 1997 representation in the upper quarter of the market income distribution increased five-fold for white women and ten-fold for black women (admittedly, in the latter case, from a very low base). Equally, examining data for the UK, Goldthorpe and McKnight (2006) find that while age/earnings profiles for women in higher-level occupations in 1975 resembled those of women in lower-level occupations, by 1999 they were aligned on the higher and significantly steeper profiles for men.

These moves towards gender equality in pay have given rise to increased dispersion in the overall income distribution not only directly but also through assortative mating, i.e. the tendency for more highly educated men to marry more highly educated women - with the OECD (2011: 207) estimating that after the change in the dispersion of male earnings, assortative mating was the second largest contributor to the increase in the inter-decile ratio of Australian household incomes (that is, the ratio of market earnings in the top to the bottom decile).

There has, to that extent, been a decrease in between-group inequality matched by a corresponding rise in within-group and aggregate inequality. Put simply, as women earned a market return that better reflected their skills, the effect was to increase the variance of women's incomes (as between low and high skill women) and of incomes overall. But is difficult to see how that could be a bad thing - on the contrary, it is the largely predictable result of decreasing inequality between segments of society (as anticipated in Rae, 1981).

Secondly, cross-sectional measures of income distribution (that is, the distribution across the relevant population at one point in time) may obscure changes that work through income variation over time (i.e. longitudinally) and that potentially increase dispersion in a cross-sectional sense while not doing so (and indeed raising all or most incomes) over lifetimes.

Consider, for example, declines in the depreciation rate of individuals' earnings abilities, i.e. the postponement, perhaps as a result of the greater share of human capital in individual's bundle of capabilities or of improved overall health, of the age at which the returns to experience decline. Such a postponement, if it leaves mean incomes unchanged (and so is mean-preserving in income for a given stock of experience and education) increases the slope of age/earnings profiles in the Mincerian equation relating wages to education and experience; it therefore increases inequality in the cross-sectional income distribution (Welch, 1999). However, over time, all currently less experienced workers will become more experienced, and so for a pure mean-preserving change, lifetime inequality is unchanged. And if the fall in the depreciation rate increases incomes and more generally wellbeing, as is likely, this change too is to be welcomed rather than condemned. 
Third and last, a similar problem with cross-sectional distributions arises from changes in risk-aversion.

As Friedman and Savage noted in their classic paper on choice under uncertainty, 'occupations differ greatly in the variability of the incomes they offer, (and) individuals, in choosing among occupations, are making choices analogous to those they make when they decide whether to buy insurance or to gamble' (Friedman and Savage, 1948: 279). This is important because as incomes rise, individuals should become more willing to bear risk. ${ }^{5}$ As societies grow richer, one would therefore expect a greater share of economic activity to involve relatively risky choices, which in turn gives rise to a higher dispersion of realised income in each period (Halaby, 2003).

Over time, however, repeated risky bets will yield a lifetime distribution of returns that is more equal, while consumption smoothing will ensure the distribution of consumption is less unequal than the cross-sectional distribution of income. Moreover, the greater willingness to bear risk - be it through the choice of self-employment, of riskier forms of dependent employment and/or of increased investment in relatively risky financial assets - will increase incomes overall (as the cost of risk bearing falls), making this change also one to be welcomed.

It is difficult to know how large an impact changes in risk aversion have had on overall changes in income distribution. While the dispersion of incomes from self-employment has increased, accounting decompositions suggest these have made a relatively small contribution to increased dispersion in earnings (OECD, 2011: 238). As for the impact of returns on financial assets, these too made a small, but in this case rising, contribution to measured inequality, though less so in Australia than elsewhere (OECD, 2011: 239). Shifts towards riskier forms of employment have not, however, been considered in the literature, though there is evidence that the use of forms of remuneration more dependent on performance, and hence involving greater risk, has made a significant contribution to increased earnings dispersion, at least in the United States (Lemieux, Bentley MacLeod and Parent, 2007).

None of this, however, is to deny that the main source of changes in the earnings dispersion in the advanced economies concerns increases in the returns to skill, and especially to the higher levels of skill (relative both to low-level skills and to mid-level, routine, skills). This reflects a combination of skill-biased technological change (Goldin and Katz, 2008) and of factors that increase the international tradeability of routine information processing tasks (Acemoglu and

5 If individuals have roughly constant relative risk aversion, absolute risk aversion decreases significantly with income. For instance, with log utility, in which utility $=\mathrm{LN}(\mathrm{c})$, absolute risk aversion is $(1 / \mathrm{c})$, so individuals with one-tenth as much ' $\mathrm{c}$ ' have ten times as high a level of absolute risk aversion. 
Autor, 2010). In the immediate, such a change has winners and losers, though on net, the benefits are likely to be substantial. Without changes in relative earnings, however, the signals to adjust to that change would be weakened, and in particular, the incentives for long-term skill acquisition would be reduced.

As a result, while this change can create immediate issues for those whose relative market earnings have declined (and obviously so if their earnings decline in absolute terms), the key long run issue is with whether adaptation can occur to an increased skill premium - an issue considered in the discussion of policy proposals below.

\section{Not all reductions in inequality are good for you}

Just as not all increases in conventional measures of income dispersion are bad, so not all reductions in dispersion are good.

A striking case, with some relevance to current Australian policy debates, is that of wage compression associated with collective bargaining and employment protection laws. ${ }^{6}$ As a general matter, international comparisons show that stronger unions and higher levels of collective bargaining are associated with a narrower wage and earnings spread, as are more stringent employment protection laws (Blau and Kahn, 1996). Those narrower wage spreads reduce labour force participation rates, especially among the unskilled (Blau and Kahn, 1996). Moreover, while employment protection laws reduce the rate at which protected workers transition to unemployment, they increase the duration of those spells of unemployment, with the second effect being greater than the first (Blanchard and Portugal, 1998).

As a result, employment protection laws lead to a higher equilibrium rate of unemployment. So as to counter that effect, since the 1990s many governments have granted exemptions to the laws for workers on temporary or contingent contracts, allowing those contracts to act as a pressure valve in the labour market (Rueda, 2008). The overall impact is twofold: a compression of wage differentials, reducing measured dispersion in the earnings distribution (Atkinson and Brandolini, 2006); and a sharp split in the labour market between 'insiders' and 'outsiders', with the former in highly protected jobs while the latter bear the vast brunt of cyclical and structural changes.

6 Employment protection laws impose restrictions on the ability of employers to dismiss employees or alter their conditions of employment. They affect earnings by changing the distribution of bargaining power between employers and the protected employees and make it easier for unions to secure agreements that provide rents to the employees with the greatest weight in union decision-making. 
In France, for instance, one of the few OECD countries where the wage dispersion has fallen over time, temporary employment contracts account for some nine per cent of all jobs but generate 80 per cent of employment turnover in French establishments (DiPrete, Goux, Maurin and Quesnel-Vallee, 2006). Workers on temporary contracts face a risk of unemployment that is up to ten times greater than that of permanent employees, both because the hazard rate is so high and because their unemployment durations are long (Maurin, 2010). Moreover, that higher risk is not offset by higher expected earnings when in employment. The resulting differential in risk exposure therefore amounts to a reduction in the 'full wage', relative to the nominal rate of pay; but that reduction is not reflected in the income distribution data, which consequently understates the dispersion in effective income.

The economic costs of these distortions obviously go far beyond the understatement of income inequality. High turnover in temporary jobs - whose duration is usually limited by statute - discourages employers from investing in employee skills, thereby preventing employees from accumulating experience that would increase their lifetime earnings, which reduces the rate of growth of productivity (Dolado and Stucchi, 2008). At the same time, the difference in effective (risk-adjusted) earnings between insiders and outsiders increases competition for the protected jobs, leading to costly forms of rent dissipation, including over-investment in credentialing (Maurin, 2010). Additionally and somewhat paradoxically, international comparisons of public opinion surveys show that stronger laws against dismissal increase insiders' fear of being made redundant, doubtless because the consequences of losing one's job are so severe in terms of the likely duration of unemployment and the associated permanent income loss (Clark and Postel-Vinay, 2008). The result is a stronger correlation between earnings and perceived income insecurity than in countries with more flexible labour markets, setting the basis for politically powerful coalitions that push for high public employment and generous welfare benefits (Rehm, Hacker and Schlesinger, 2012), with fiscal consequences all too apparent in Europe's current difficulties.

The fact that the measured dispersion of labour income has increased less in countries with stringent employment protection laws is therefore hardly an indication of success. But all this is missed in simple comparisons of crosssectional income distributions, which regularly imply that narrower means better. 


\section{Some changes could be bad for you}

None of that, however, implies the appropriate attitude to changes in income distribution is one of indifference. Rather, cogent concerns have been expressed about the risks of hardship for those at the bottom, the dangers of privilege accruing to those at the top, and the longer-term implications of a widening income distribution for mobility and equality of opportunity. But while these issues cannot be dismissed lightly, they do need to be kept in perspective. I consider each of them in turn.

\section{Poverty}

At least in Australia, the persistence of poverty is reasonably close to the OECD average (OECD, 2008: 157-8, 171), with the HILDA data suggesting relatively low three-year persistence. Moreover, even for those at the bottom of the distribution, rising incomes reduce the risk of relative deprivation: if poverty is defined as an income lower than half the median income of a decade earlier (rather than with respect to the median income of today), the proportion in poverty is reduced by over 50 per cent and is reasonably low by international standards (OECD, 2008: 130). Additionally, the poverty gap - defined as the proportion of the poor living with disposable incomes far below the poverty line - is low, absolutely and by international standards (OECD, 2008: 128), again suggesting a risk of hardship that is low and likely to be tightly localised in groups with multiple sources of disadvantage, such as Indigenous Australians.

All this confirms the more general, but crucial, point that the distribution of consumption is far more equal than that of income: for instance, a recent study by the ABS using national accounts data finds that while the inter-quintile ratio ${ }^{7}$ for wages and salaries is in the order of 6.5, the inter-quintile ratio for actual individual consumption is only 1.6 (Smedes, 2012), reflecting consumption smoothing and the redistributive impact of taxes and transfers. Even assuming some error in these ABS estimates, other ABS sources (notably the Household Expenditure Survey, which may have the opposite bias) suggest a consumption gap of around three to one, which is still a very significant reduction relative to the difference in wages and salaries.

That hardly means there are no concerns: the plight of localised groups, especially Indigenous Australians, calls for a more effective policy response. Additionally, a point stressed in Castles (1984 and 1990) seems relevant. Castles noted that prices for income-inelastic goods, relative to those for income-elastic goods, were low in Australia, compared to the other countries for which he had

7 The ratio of the relevant share to the top quintile to that share for the bottom quintile. 
data (the United States, Sweden and Japan). That increased the relative living standards of low-income households, as did the abundant availability of lowpriced or un-priced resources (such as camping grounds and playing fields). ${ }^{8}$

In recent years, however, charges for utilities, public transport and governmentprovided facilities have risen sharply, with especially steep increases in water and electricity prices (RBA, 2012:61). While those increases have been to a degree offset by income transfers, taper provisions in the compensation tend to increase effective marginal tax rates, accentuating the disincentives for full-time work and increasing the risk of 'poverty traps'.

\section{Top incomes}

Seen in international perspective, the income share of the top one per cent of income earners tends to move relatively closely with aggregate concentration (Leigh, 2007). In Australia, the increase in that share has been modest: the income share of the top five per cent of income earners rose from 16 per cent in 1973 to around 20 per cent in 2009/10 - still far below the 40 per cent level it reached in 1922 .

In relative terms, the trend since the 1980s is very similar to the trend in other rich English-speaking countries, with the share for the richest one per cent of taxpayers roughly doubling from five per cent to 10 per cent between 1980 and 2007. It is worth noting, however, that the share of the top one per cent was in comparative terms very low in 1979-80, so that the doubling of the income share put Australia post-2000 in the same range as France and Japan, but significantly lower than Canada or the United Kingdom, and about half the share of the richest one per cent in the USA. ${ }^{9}$

Nonetheless, as the former Treasurer's recent essay shows (Swan, 2012), few issues have raised as much ire, bearing out both Tocqueville's observation that democracy can fan 'a debased taste for equality' (Tocqueville, 1969: 57) and Hancock's conclusion that Australians - a people that 'loves oratory, and does not love statistics' - are inclined to be 'merciful to the average' and suspicious of the best, indulging the 'destructive vandalism of the weak' (Hancock, 1931: $143,146,304)$. Yet there is no shortage of factors that would lead one to expect the top income share to have increased in recent decades. These include:

- The rapidly growing absolute size of firms and their internationalisation, which has increased the size of managerial hierarchies and intensified international competition for talent, with the largest benefits accruing to

8 For instance, Castles estimated that on a per capita basis, Sydney residents had access to four times as many public open space sites as residents in Kyoto and eight times as many as residents in Tokyo. As for public playing fields and tennis courts, these were ten to twenty times greater (Castles, 1990:15-16).

9 I am grateful to Peter Whiteford for the data presented in this paragraph. 
English-speaking executives (reflecting the role of English as the lingua franca of global business);

- More intense product market competition and improvements in corporate governance, which have also increased the returns on management skill and intensified competition in managerial labour markets;

- Better techniques for monitoring and measuring executive performance, which have increased the role of performance-related pay and allowed the highest performing managers to capture a greater part of the potential gains from trade; ${ }^{10}$ and

- Reductions in top marginal tax rates, which may have increased labour effort by the top decile. ${ }^{11}$

Indeed, the vast literature on the rise in top earnings finds that any one of these contributes significantly to the trend, and that many suffice, or come close to sufficing, to explain the entire observed change (see for instance Veall, 2012). As a result, a higher share of top earners in the overall income distribution is in itself no indication of inefficiency.

Additionally, as with poverty, persistence at the top of the Australian income distribution seems to be relatively low, with an annual exit rate from the highest one per cent of income earners that, at nearly 40 per cent, is significantly above that in Canada (where it is around 30 per cent) and the United States (around 27 per cent) (OECD, 2011: 353). ${ }^{12}$ Also high is the effective average tax rate on Australian top income earners, which is three percentage points higher than that in Canada, five percentage points higher than that in Sweden and 10 percentage points higher than that in the United States (OECD, 2011: 363). ${ }^{13}$

That said, it is true that the assistance provided to the financial system during the Global Financial Crisis may create significant issues of moral hazard going forward, including in terms of executive pay; but those issues seem best addressed directly, rather than being a question of the long-run trend in the income distribution as such.

As a result, it is difficult to put much weight on the concerns that have been expressed about top incomes, at least from an economic perspective. However,

10 These techniques reduce agency problems in the shareholder-manager relationship and hence reduce the waste those problems create in terms of foregone productivity improvements (the 'agency loss'). This increases the gain to hiring good managers and hence should give rise to higher earnings.

11 The OECD provides data for the top quintile, which shows a slight increase in hours worked - see OECD, 2011:188.

12 Paul Samuelson used to quote Schumpeter to the effect that the top floor in capitalism's best hotels was invariably full, but always with different people. Turnover rates of 30 per cent or more are certainly reminiscent of Schumpeter's bon mot.

13 As Peter Whiteford has pointed out to me, these estimates refer to labour income taxes and do not include social security contributions. However, social security contributions are usually slightly regressive, so excluding them is unlikely to change the international comparison. Moreover, for Australia, they do not include the superannuation guarantee. 
those concerns have been paralleled by claims that a rising share of top incomes could compromise the functioning of democratic institutions. The explicit or implied parallel is with the United States where, it is argued, political donations distort the democratic process.

These claims are difficult to evaluate. There is no doubt politics has become more capital intensive (Aldrich, 1995); the question is whether that has allowed the very wealthy, as their share of aggregate income rises, to exercise greater influence. At least as matters now stand, the evidence is inconclusive. Morris Fiorina, a leading contemporary scholar of American politics, does not list income shares as a factor affecting the current difficulties of the American political system (Fiorina, 2009), although there are scholars who have come to the opposite conclusion (Gilens, 2012). As for the recent highly critical study by leading scholars Thomas Mann and Norman Ornstein, while they are deeply concerned by the role of money in US politics, they regard it as essentially a second order issue and term reform proposals 'quixotic', though that may reflect pessimism as to the prospects for change (Mann and Ornstein, 2012:127-130). Meanwhile, research into Congressional voting patterns finds that very broad interest groups - such as those representing retirees, public sector employees and environmentalists - are as effective as narrower interest groups, and in some cases more so, in shaping agendas and outcomes (Grossmann, 2012; and Trumbull, 2012).

Given mixed findings for the United States, the contention that the far more limited increase in the share of top earners in the Australian income distribution threatens democracy seems exaggerated. This is all the more the case given the characteristics of the Australian political system, including the relatively centralised nature of the political parties and the fact that unions - not wealthy individuals - are the largest and most stable source of external resource transfers (with almost all of the transfers unions make going to a single party).

None of that is to deny that wealthy individuals have recently played an important role in Australian politics, with the influence of property developers on the New South Wales Labor government being well documented (Cavalier, 2102) and giving rise to seemingly serious issues of corruption (Freestone and Williams, 2012:204-5). That said, the roots of the problem lie less in income distribution than in government policies (particularly with respect to land use and planning restrictions) that create rents politicians can allocate on a discretionary basis - indeed, the distortions to income distribution (in terms of the high returns to certain forms of property development) have tended to arise from, rather than cause, the government policies, although they may then ensure those policies are perpetuated. As a result, those issues seem best addressed by reforming policy so as to remove the rents at issue, together with 
increased transparency, tighter controls on political donations (including by unions) and strengthened measures against corruption, rather than by tinkering with the overall distribution of income. ${ }^{14}$

\section{Social mobility}

This leads to the third and final source of concern which is with longer-run social mobility. Ultimately, social mobility goes to equality of opportunity, which is not only a core element in the legitimacy of market systems but also central to efficiency: if talent is widely distributed across income groups, precluding the talented children of poorer people from contending for the more senior positions in society, while reserving some of those positions for the less talented offspring of richer people, is an inefficient allocation of resources. The question is therefore whether increased inequality in the distribution of incomes reduces social mobility, and hence results in such an inefficiency.

As typically defined, equality of opportunity involves an equal chance to participate in the race, rather than an equal chance to win it - as the chances of winning should be sensitive to ability, which is at least partly inheritable. ${ }^{15}$ Those chances are also sensitive to attributes such as diligence and ambition, that even staunch egalitarians (for instance Dardarnoni, Fields, Roemer and Puerta, 2006) recognise ought to affect outcomes, despite their correlation with family background. That recognition notwithstanding, economists and sociologists typically assess the degree to which there is equality of opportunity by examining outcomes rather than prospects, and in particular, by measuring the correlation between parental income (or education) and the income (or education) of children. ${ }^{16}$

This creates an obvious difficulty, in that it is hardly clear how high or low this coefficient needs to be to correspond to 'equal opportunity' - a difficulty made all the greater by the somewhat counterintuitive fact that the intergenerational correlation in outcomes will be higher the larger the variance of talent in the population, the more important talent is in determining outcomes and the more efficient is education in complementing talent (Grawe and Mulligan, 2002; Jencks and Tach, 2006). That said, the best estimate for the United States is that genetic factors associated with the inheritance of talent account for one third to

14 This is all the more the case as many of the instances of corruption involved developers who operated on a relatively small, local scale and were far from being part of the 'top .01\%'.

15 John Rawls, for example, defines 'fair equality of opportunity' as meaning that 'those with similar abilities and skills ... and (who) have the same willingness to use them, should have the same prospects of success regardless of their initial place in the social system' (Rawls, 1971:73).

16 In some cases, the focus is not on the intergenerational correlation but on the coefficient in a regression equation relating parental attributes to those of children. The links between these parameters, and the issues involved in their interpretation, are analysed in Jencks and Tach, 2006. 
one half of the observed intergenerational correlation (Jencks and Tach, 2006), with other factors (such as attitude and values) possibly accounting for another third (as suggested by Dardarnoni, Fields, Roemer and Puerta, 2006).

Assuming inheritability is no lower in Australia than in the United States, and given that the absolute size of the intergenerational persistence coefficient is significantly lower in Australia than in the United States (Blanden, 2009; Björklund and Salvanes, 2011), there is little reason to believe Australia does not provide 'equal opportunity', at least for non-indigenous Australians. The strong demand for permanent residence in Australia by migrants whose aspirations largely involve upward mobility by their children seems to confirm the view that Australia still provides great scope for social advancement. ${ }^{17}$

The question nonetheless is whether an increase in income inequality is likely to compromise equality of opportunity going forward. The answer is that there is not strong evidence to believe it would. To begin with, the relationship, even on a cross-sectional basis, between income distribution and social mobility is far from clear-cut: France has a significantly lower Gini coefficient than Canada or Australia, but significantly higher intergenerational persistence, i.e. lower mobility (Smeeding, Erikson and Jäntti, 2011). Moreover, even within countries, significant increases in measured income inequality do not appear to have reduced social mobility, possibly reflecting the fact that greater inequality increases the incentive to invest in achieving upward mobility, even if it increases its difficulty (Blanden, 2009; Erikson and Goldthorpe, 2010; and Lee and Solon, 2008). And of course, an increase in the earnings dispersion may itself reflect an increase in mobility, if it arises from an increase in the importance of talent as a determinant of the earnings distribution (Jencks and Tach, 2006; and Grawe and Mulligan, 2002).

Ultimately, the differences in social mobility between advanced market economies are surprisingly small - as Blanden (2009) points out, even the large gap in measured intergenerational persistence between Sweden and the United States is not statistically significant. That is perhaps unsurprising: there is an openness, common to those economies, that creates scope for talent and movement. Changes in the income distribution, especially on the rather limited scale of recent years, seem unlikely to materially alter that picture, at least at an aggregate level. ${ }^{18}$

17 Indeed, in my view, there is great, under-utilised, scope to use migrant demand for entry and permanent residence as between possible host countries as an indicator of relative quality of life and of social mobility. 18 They may nonetheless worsen poverty traps for particular groups in the population, which are perhaps best dealt with through targeted responses (though the efficacy of those responses has, at least so far, not been especially high). 


\section{Fashionable policy responses may do more harm than good}

In short, while the changes that have occurred in the distribution of income raise legitimate questions, there is little reason to think they have been grossly problematic. Moreover, many aspects of those changes reflect factors that increase both efficiency and equity. That notwithstanding, they have given rise to myriad policy proposals, and especially to suggestions that spending should be increased on education, that taxes should be raised on high incomes and that some form of bequest tax should be introduced. I now turn to consider, somewhat sceptically, each of these proposals.

\section{Increased spending on education}

The observed increase in the returns to skill is suggestive of an increase in the private and (potentially) social returns on education, leading to proposals for greater public spending on education as a way of assisting individuals to adjust and of promoting social mobility.

Underlying these proposals is the presumption that individuals and families are credit constrained (and hence cannot realise their desired level of investment in skills) and/or that there are social returns to education that exceed the private returns (and hence result in under-investment). Moreover, assuming initial levels of public spending are reasonable, the arguments for an increase must involve some increase in these underlying factors - i.e. a greater likelihood of credit constraints or of externalities preventing existing efforts from attaining efficient outcomes.

There is no evidence of an increase in the externalities associated with education - indeed, greater private returns to skills suggest individuals are capturing at least a reasonable share of the increased social value of education and experience. Indeed, if performance measurement in the workplace has improved, it may be that individuals are capturing an increased share of that social value.

As for credit constraints, the theory seems to be that a widening in the income distribution increases the risk that low-income households will be unable to finance the investment they would wish to make in skill development, restricting adjustments to changes in labour demand by current workers and reducing social mobility between generations. In practice, however, a general increase in spending on education would be a poorly targeted way of dealing with adjustment by the existing generation of workers; the question must therefore be whether it would facilitate otherwise unachievable but desirable social mobility between generations and do so in a manner that involved benefits that exceeded the spending's opportunity costs. 
That spending increases would meet these criteria is at best unproven.

To begin with, relatively little is known about the degree to which credit constraints restrict social mobility, ${ }^{19}$ and even less about whether those constraints have become more binding. It would be surprising if they had, given that incomes have increased significantly at all points in the income distribution and that relatively generous financial assistance is already provided to education.

Additionally, there is little evidence to suggest that the extent to which educational systems entrench or offset family background effects bears any simple relationship to public spending on education, at least at the levels of expenditure typical of advanced economies. Rather, the characteristics of educational systems (for instance, in terms of decentralisation and choice) seem a more important determinant (Schuetz, Ursprung and Woessmann, 2008; Björklund and Salvanes, 2011; and Hanuschek and Woessman, 2011). Without structural reform of those systems, it is unclear why greater spending would lead to better outcomes - and with structural reform, it may not be needed or efficient (in the sense of yielding benefits that exceed costs).

Last and related, the possibility must be acknowledged that increased public spending, rather than benefiting social mobility, would largely be captured by the providers of education, or would simply strengthen the advantage of those who could fund education for themselves, while crowding out potentially more efficient private efforts (Peltzman, 1973; Checchi, Ichino and Rustichini, 1999; and Jencks and Tach, 2006). ${ }^{20}$

As a result, the best that can be said for this proposal is that the case in its support has not been made.

\section{Increased taxes on the rich}

Proposals to increase effective tax rates on very high incomes have almost invariably accompanied expressions of concern about the rise in top incomes and have even been taken up by the OECD (see OECD, 2008 and 2011). However, as noted above, effective average tax rates on high incomes are already high in Australia by international standards, and the question must be what impact increases in those tax rates would have.

19 The extent to which credit constraints bind social mobility depends on the joint distribution of educational potential and financial resources (Becker and Tomes, 1979; Grawe and Mulligan, 2002); in countries which are already relatively meritocratic, the partial inheritability of ability implies this is most likely to be an issue in middle-income families, a supposition borne out by evidence for Canada (see Corak and Heisz, 1999) and hence is unlikely to be much affected by a widening of the income distribution at its tails. 20 The fact that families with far lower income levels have made and continue to make large investments in education in the rapidly growing Asian economies, and that those investments seem relatively effective both in terms of educational outcomes and of social mobility, is certainly consistent with this possibility. See James and Benjamin, 1988 and Lynn, 1988 on Japan, Amsden 1989 on Korea and Lemos, 2012 on China. 
This can be seen by considering the revenue-maximising tax rate - i.e. the rate that raises the greatest revenue from top-income earners, regardless of its efficiency consequences. That rate can be calculated using some simple parameters of the income distribution and of the elasticity of taxable income (which is usually defined in terms of the response of income to the share of income a taxpayer retains, and hence is a positive number: for estimates, see Gruber and Saez, 2002). ${ }^{21}$ Thus, using Canadian parameters for the top income distribution (Veall, 2012: 33) the revenue from a marginal increase, starting from an initial marginal rate of 50 per cent, ${ }^{22}$ is negative for values of the elasticity of taxable income above 0.6 , which is within the range of reasonable estimates.

It is therefore not apparent that an increase in the tax rate would raise any revenue - rather, it could place the tax on the wrong side of the Laffer curve. At the same time, half or more of the response would be a real fall in social output, reducing welfare. This could, in other words, be an exercise in cutting off one's nose to spite one's face, which is hardly a sensible basis for public policy.

\section{Bequest taxes}

A final proposal, again commonly associated with concerns about top incomes, is to introduce taxes on bequests or other forms of inheritance. As with all other taxes, these have obvious incentive problems, aggravated by the fact that inter vivos gifts must be policed to prevent evasion. But there is a more fundamental incoherence in these taxes, at least as a way of enhancing social mobility.

In effect, if dynastically aware families ${ }^{23}$ face a choice between investing in the education and general integration into working life of their children on the one hand, or investing in financial assets on the other (as in Becker and Tomes, 1979), a tax on bequests simply leads to an inefficient shift in the composition of investment to the former. This has the perverse result of increasing educational inequality (Grawe and Mulligan, 2002). It is difficult to believe this is the outcome its proponents have in mind. While the extent of any such effect is an empirical question, it does emphasise the need for a more sophisticated approach to such taxes than their advocates usually display.

\footnotetext{
21 The formula for the maximum revenue raising tax rate is $1 /(1+e a)$, where $e$ is the elasticity of taxable income and $a$ is the Pareto coefficient.

22 This is not an unreasonable starting point, given an average effective rate of about 40 per cent (OECD, 2011: Table 9.7), a consumption tax of 10 per cent and a payroll tax of say three per cent. Veall sets out the Canadian and international estimates, defining the marginal increase in terms of the tax that raises an additional dollar, assuming no behavioural response.

23 That is, families that internalise the welfare of future generations.
} 


\section{Conclusions}

Public attitudes to income distribution, and public policies in respect of income distribution, are relatively closely related to beliefs about the inherent justice or otherwise of social outcomes (Bénabou and Tirole, 2006; Brooks and Manza, 2006; and Jasso, 1999). They also reflect the public's beliefs about the inherent legitimacy, costs and effectiveness of redistribution (McCall, 2012). The focus on executive pay arising from the GFC, combined with long-run shifts in income distribution, are likely to have affected those aspects of public opinion, at least potentially creating pressures for further government intervention.

Yet there is little reason to believe that there is a serious problem in Australia with income distribution. While the distribution of market incomes has widened slightly, that seems related to factors that are likely to increase efficiency and in some cases (such as the closing of gender gaps in pay) equity. Moreover, despite that widening, market incomes at all levels of the income distribution have increased strongly. In contrast, at least some countries that have adopted policies that narrow the distribution of market incomes - such as employment protections laws and measures aimed at promoting collective bargaining or centralising wage setting - have not only suffered in terms of economic growth but also in terms of equity. And many of the policies advocated by local supporters of redistribution could well have the same effect. Paying close attention to the lessons of international experience, as Castles so clearly did, should be crucial in assessing the risks those policies involve.

\section{References}

Acemoglu, D and Autor, D (2010). 'Skills, Tasks and Technologies: Implications for Employment and Earnings', National Bureau of Economic Research Working Paper Series, Working Paper 16082.

Aldrich, John H (1995). Why Parties? The Origin and Transformation of Political Parties, University of Chicago Press, Chicago.

Almås, I (2012). 'International Income Inequality: Measuring PPP Bias by Estimating Engel Curves for Food', American Economic Review, 102(1): 10931117.

Atkinson, AB and Brandolini, A (2006). 'The Panel-of-Countries Approach to Explaining Income Inequality: An Interdisciplinary Research Agenda', in Morgan, SL, Grusky, DB and Fields GS (eds), Mobility and Inequality, Stanford University Press, Stanford CA. 
Becker, GS and Tomes, N (1979). 'An Equilibrium Theory of the Distribution of Income and Intergenerational Mobility', Journal of Political Economy, 87(6): 1153-1190.

Bénabou, R and Tirole, J (2006). 'Belief in a Just World and Redistributive Politics', The Quarterly Journal of Economics, 121(2): 699-746.

Berry, MJ (1977). 'Inequality' in Davies et al Australian Society: a sociological introduction, Longman Cheshire, Melbourne: 18-54,

Björklund, A and Salvanes, KG (2011). 'Education and Family Background: Mechanisms and Policies', in Hanushek, EA, Machin, S and Woessman, L (eds) Handbook of the Economics of Education, Volume 3, Elsevier, Amsterdam.

Blackburn, M (1989). 'Interpreting the Magnitude of Changes in Measures of Income Inequality', Journal of Econometrics, 42: 21-25

Blanden, J (2009). 'How Much Can We Learn From International Comparisons of Intergenerational Mobility?', Centre for the Economics of Education, CEE DP 111, London School of Economics.

Blanchard, O and Portugal, P (1998). 'What hides behind an unemployment rate: comparing Portuguese and US Unemployment', National Bureau of Economic Research Working Paper Series, Working Paper 6636.

Blau, FD and Kahn, LM, (1996). 'International Differences in Male Wage Inequality: Institutions versus Market Forces', Journal of Political Economy, 104 (4): 791-837.

Brooks, C and Manza, J (2006), 'Why Do Welfare States Persist?', Journal of Politics, 68 (4): 816-827.

Castles, I and others (1973). 'Economic Growth: Is it Worth Having?', Treasury Economic Paper No. 2, Australian Government Publishing Service, Canberra.

Castles, I (1984). 'Money income distribution and redistribution in Australia, Sweden and the United States', Paper presented to the $57^{\text {th }}$ ANZAAS Congress $24^{\text {th }}$ August 1987, James Cook University of North Queensland, Australian Bureau of Statistics.

Castles, I (1990). 'Living Standards in Sydney and Japanese cities: A Comparison', manuscript subsquently published (1994) in 'The Australian economy in the Japanese mirror', Sheridan, K (ed), University of Queensland Press, St Lucia, Queensland.

Castles, I (1997a). 'Measuring Economic Progress: From Political Arithmetick to Social Accounts', Economic Analysis and Policy, 28(2): 137-146. 
Castles, I (1997b). 'Measuring Wealth and Welfare: why HDI and GPI fail', Paper presented to the Academy of Social Sciences in Australia Symposium: Wealth, Work, Well-Being... , 10 $0^{\text {th }}$ November 1997.

Cavalier, R (2012). 'The Labor Party' in Clune, D and R Smith Labor in Office in NSW 1995-2011, Allen \& Unwin, Sydney: 3-14.

Cohen, GA (2009). Why Not Socialism?, Princeton University Press, Princeton, N.J.

Checchi, D, Ichino A and Rustichini, A (1999). 'More equal but less mobile? Education financing and intergenerational mobility in Italy and in the US', Journal of Public Economics, 74: 351-393.

Clark, A and Postel-Vinay, F (2008). 'Job security and job protection', Oxford Economic Papers, 61: 207-239.

Corak M and Heisz, A (1999). 'The Intergenerational Earnings and Income Mobility of Canadian Men: Evidence from Longitudinal Income Tax Data', Journal of Human Resources, 34(3): 504-533.

Dardarnoni, V, Fields, GS, Roemer, J and Puerta, MLS (2006). 'How Demanding should Equality of Opportunity Be, and How Much Have We Achieved?' 'in Morgan, SL, Grusky, DB, and Fields GS (eds), Mobility and Inequality, Stanford University Press, Stanford CA.

Davies, AF, Encel, S and Berry, MJ (eds) (1977). 'Australian society: a sociological introduction', Longman Cheshire, Melbourne.

de Tocqueville, A (1969). Democracy in America, Lawrence, G. (tr), Mayer, JP (ed), Doubleday, Garden City NY.

DiPrete, TA, Goux, D, Maurin, E, and Quesnel-Vallee, A (2006). 'Work and pay in flexible and regulated labor markets: A generalized perspective on institutional evolution and inequality trends in Europe and the US', Research in Social Stratification and Mobility, 24: 311-332.

Dolado, JJ and Stucchi, R (2008). 'Do temporary contracts affect TFP? Evidence from Spanish Manufacturing firms', IZA Discussion papers No. 3832.

Erikson, R and Goldthorpe, JH (2010). ‘Has social mobility in Britain decreased? Reconciling divergent findings on income and class mobility', The British Journal of Sociology, 61(2): 211-230.

Fiorina, MP with Abrams, SJ (2009). Disconnect: the Breakdown of Representation in American Politics, University of Oklahoma Press: Norman. 
Freestone, R and P Williams (2012). 'Urban Planning' in Clune, D. and R. Smith Labor in Office in NSW 1995-2011, Allen \& Unwin, Sydney: 193-206.

Friedman, M and Savage, LJ (1948). 'The Utility Analysis of Choices Involving Risk', Journal of Political Economy, 56(4): 279-304.

Galbraith, JK (1958). The Affluent Society, The Houghton Mifflin Company, Cambridge, MA.

Gilens, S (2012). Affluence and Influence: Economic Inequality and Political Power in America, Princeton University Press: Princeton, N.J.

Goldin, C and Katz, LF (2008). The Race between Education and Technology, Harvard University Press, Cambridge MA.

Goldthorpe, J and McKnight, A (2006). 'The Economic Basis of Social Class' 'in Morgan, SL, Grusky, DB, and Fields GS (eds), Mobility and Inequality, Stanford University Press, Stanford CA.

Grossmann, M (2012). The Not-So-Special Interests: Interest Groups, Public Representation, and American Governance, Stanford University Press, Stanford CA.

Grawe, N and Mulligan, C (2002). 'Economic Interpretations of Intergenerational Correlations', The Journal of Economic Perspectives, 16 (3): 45-58.

Gruber, J and Saez, E (2002). 'The elasticity of taxable income: evidence and implications', Journal of Public Economics, 84: 1-32.

Halaby, CN (2003). 'Where Job Values Come from: Family and Schooling Background, Cognitive Ability, and Gender', American Sociological Review, 68 (2): 251-278.

Hancock, WK (1930). Australia, Ernest Benn, London.

Hanuschek, EA and Woessman, L (2011). 'The Economics of International Differences in Educational Achievement', in Hanushek, EA, Machin, S and Woessman, L (eds) Handbook of the Economics of Education, Volume 3, North Holland, Amsterdam.

James, E and Benjamin, G (1988) Public Policy and Private Education in Japan, Macmillan Press.

Jasso, G (1999). 'How Much Injustice is There in the World? Two New Justice Indexes', American Sociological Review, 64(1): 133-168. 
Jencks, C and Tach, L (2006). 'Would Equal Opportunity Mean More Mobility?' in Morgan, SL, Grusky, DB, and Fields GS (eds), Mobility and Inequality, Stanford University Press, Stanford CA.

Kuznets, S (1955). 'Economic Growth and Income Inequality', The American Economic Review, 45(1): 1-28.

Lee, C-I and Solon, G (2008). 'Trends in Intergenerational Income Mobility', The Review of Economics and Statistics, 91(4): 766-772.

Leigh, A (2007). 'How Closely Do Top Income Shares Track Other Measures Of Inequality?', The Economic Journal, 117: 619-F633.

Lemieux, T, Bentley MacLeod, W and Parent, D (2007) 'Performance Pay and Wage Inequality', National Bureau of Economic Research Working Paper Series, Working Paper 13128.

Lemos, G (2012). The End of the Chinese Dream: Why Chinese people fear the future, Yale University Press, New Haven and London.

Lynn, R (1988). Educational Achievement in Japan, ME Sharpe, Inc, Armonk, NY.

Mann, TP and Ornstein, NJ (2012). It's Even Worse Than It Looks: How The American Constitutional System Collided With The New Politics Of Extremism, Basic Books, Perseus Books Group, New York.

Maurin, É (2010). La Peur Du Déclassement: Une Sociologie Des Récessions, La Republique des Idees, Seuil, Paris.

Morgan, SL, Grusky, DB, and Fields GS (eds), (2006). Mobility and Inequality, Stanford University Press, Stanford CA.

OECD (2008). Growing Unequal? Income Distribution and Poverty in OECD Countries, OECD, Paris.

OECD (2011). Divided We Stand: Why Inequality Keeps Rising, OECD, Paris.

Peltzman, S (1973). 'The Effect of Government Subsidies-in-Kind on Private Expenditures: The Case of Higher Education, The Journal of Political Economy, 81(1): 1-27.

Rae, D (1981). Equalities, Harvard University Press, Cambridge MA.

Rawls, J (1971). A Theory of Justice, Harvard University Press, Cambridge, MA.

Rehm, P (2011). 'Risk Inequality and the Polarized American Electorate', British Journal of Political Science, 41(2): 363-387. 
Rehm, P, Hacker JS and Schlesinger, M (2012). 'Insecure Alliances: Risk, Inequality, and Support for the Welfare State ', American Political Science Review, 106(2).

Reserve Bank of Australia (2012). Statement on Monetary Policy, Reserve Bank of Australia, Sydney.

Rueda, D (2008). Social Democracy Inside Out: Partisanship and Labor Market Policy in Advanced Industrialized Democracies, Oxford University Press, Oxford.

Schuetz, G, Ursprung, HW and Woessmann L (2008). 'Education policy and equality of opportunity', Kyklos, 61(2): 279-308.

Smedes, M (2012). 'Measuring Household Disparities in a National Accounts Framework', Presentation to the Economic Society of Australia: Seminar Series, 14 November, National Accounts Branch, Australian Bureau of Statistics.

Smeeding, TM, Erikson, R and Jäntti, M (2011). 'Introduction' in Smeeding, TM, Erikson, R and Jäntti, M (2011). Persistence, Privilege, and Parenting:The Comparative Study of Intergenerational Mobility, Russell Sage Foundation, New York, NY.

Swan, W (2012). 'The 0.01 Per Cent: The Rising Influence of Vested Interests in Australia', The Monthly, 76.

Trumbull, G (2012). Strength in Numbers: The Political Power of Weak Interests, Harvard University Press, Cambridge MA.

Veall, MR, (2012). 'Top Income Shares in Canada: Recent Trends and Policy Implications', Presidential Address to the Canadian Economics Association.

Welch, F (1999). 'In Defense of Inequality', The American Economic Review, 89 (2): $1-17$. 